\title{
Erratum to: Stand structure, floristic composition and species diversity along altitudinal gradients of a Bornean mountain range 30 years after selective logging
}

\author{
Renee Sherna LAING' ${ }^{\text {iD }}$ https://orcid.org/oooo-0oo3-2503-6889; e-mail: ren_elleenna@yahoo.com

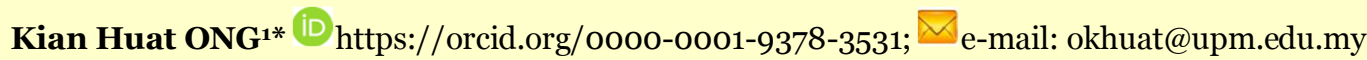

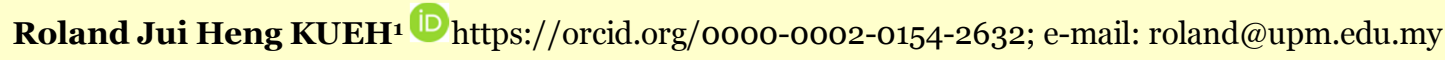 \\ Nixon Girang MANG2 iDhttps://orcid.org/oooo-ooo1-6199-4481; e-mail: nixongm@sarawak.gov.my \\ Patricia Jie Hung KING1 iD https://orcid.org/oooo-0003-4522-0165; e-mail: patricia@upm.edu.my \\ Muaish SAIT1 iD https://orcid.org/oooo-0oo3-1199-6037; e-mail: muaish@upm.edu.my

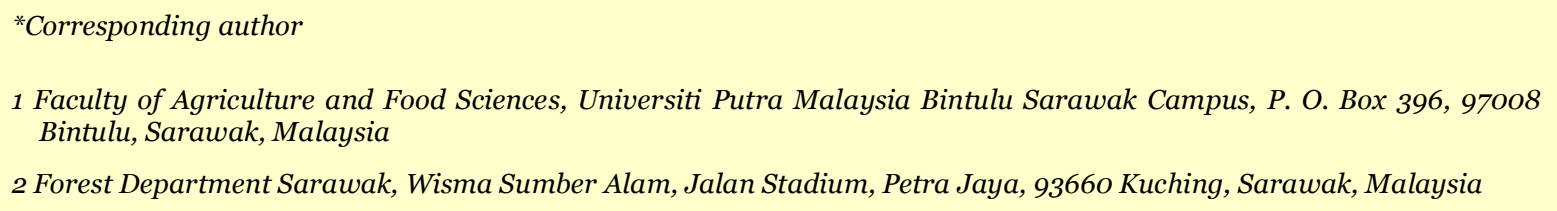

Citation: Laing RS, Ong KH, Kueh RJH, et al. (2021) Erratum to: Stand structure, floristic composition and species diversity along altitudinal gradients of a Bornean mountain range 30 years after selective logging. Journal of Mountain Science 18(8). https://doi.org/10.1007/s11629-020-6060-0

On Page 1428, Table 5 is missing. It should be placed after this paragraph "In this study, a total of 19 endemic species of Borneo were recorded (Table 5). The highest number of endemic species was found in $\mathrm{S} 1$ followed by $\mathrm{S}_{2}$ and S3. Four endemic Dipterocarpaceae (Shorea crassa at S2; Shorea isopteran, Shorea parvistipulata and Vatica micrantha at S1) were found in this study area (Table 5). Three endemic species each from Fagaceae, Lauraceae and Myrtaceae were also documented during this study (Table 5). At a similar elevation range to $\mathrm{S}_{3}$, Kueh et al. (2017) recorded 12 endemic species in their study.”. 